\title{
Evaluation of Milk Enzymes and Electrolytes, Plasma Metabolites, and Oxidative Status in Twin Cows Milked in an Automatic Milking System or Twice Daily in a Conventional Milking Parlor
}

\author{
F. Abeni, ${ }^{11}$ M. G. Terzano,† M. Speroni, ${ }^{*}$ L. Migliorati, ${ }^{*}$ M. Capelletti, ${ }^{*}$ F. Calza, ${ }^{*}$ L. Bianchi, $\ddagger$ and G. Pirlo* \\ ${ }^{*}$ Consiglio per la Ricerca e la Sperimentazione in Agricoltura, Centro di Ricerca per le Produzioni Foraggere e Lattiero-Casearie, \\ Sede distaccata per l'allevamento della vacca da latte, 26100 Cremona, Italy \\ †Consiglio per la Ricerca e la Sperimentazione in Agricoltura, Centro di Ricerca per la Produzione delle Carni ed il Miglioramento Genetico, \\ 00016 Monterotondo (Roma), Italy \\ ‡Dipartimento di Biologia Applicata, Università degli Studi di Perugia, 06121 Perugia, Italy
}

\begin{abstract}
The aim of this paper was to evaluate the effects of automatic milking (AM) on milk enzymes and minerals related to mammary epithelial integrity in comparison with twice-daily conventional milking (CM). One cow from each of 6 pairs of twins was assigned to be milked with AM or with $\mathrm{CM}$ throughout first lactation. Milk production was recorded and milk samples were collected at 4, 11, 18, 25, 32, and 39 wk of lactation (WOL) to determine fat and protein content, somatic cell count, $\mathrm{pH}$, plasminogen (pl) and plasmin (Pl) activities, $\mathrm{Na}, \mathrm{K}$, and $\mathrm{Cl}$. Body condition score was monitored; blood samples were collected to determine energy-related metabolites in the first third of lactation (14 WOL), and plasma oxidative status throughout lactation. Overall mean and standard deviation of milking frequency (MF) in AM were 2.69 and 0.88, respectively. Milk production, fat and protein contents, and somatic cell count did not differ between milking systems. The $\mathrm{pl}$ and $\mathrm{pl}+\mathrm{Pl}$ activities were lesser in $\mathrm{AM}$ than in CM. Milk pH was greater in AM than in CM. Milk $\mathrm{Na}, \mathrm{K}, \mathrm{Na} / \mathrm{K}$ ratio, and $\mathrm{Cl}$ did not differ across the whole lactation. Milk $\mathrm{pH}$ had a positive correlation with milk $\mathrm{Pl}$ activity $(\mathrm{r}=0.41), \mathrm{Na}(\mathrm{r}=0.37)$, and $\mathrm{Cl}(\mathrm{r}=$ 0.40 ) concentration, and negative correlation with the $\log _{10}$ of $\mathrm{pl} / \mathrm{Pl}$ ratio $(\mathrm{r}=-0.47)$. The milk $\mathrm{Na} / \mathrm{K}$ ratio had a positive correlation $(\mathrm{r}=0.55)$ with milk $\mathrm{Pl}$ activity. Milking system (MS) did not seem to affect mammary epithelial permeability. The differences in enzymatic (proteolytic) activity due to the MS, probably related to daily MF, lead one to suppose that the quality of the protein fraction for the cheese-making process was preserved better with AM than with CM, even if differences in $\mathrm{pH}$ might negatively interfere. No difference
\end{abstract}

Received January 21, 2008.

Accepted June 5, 2008.

${ }^{1}$ Corresponding author: fabiopalmiro.abeni@entecra.it was detected in BCS, and in plasma concentration of triglycerides and nonesterified fatty acids, whereas plasma cholesterol concentration during the first 10 WOL was lesser in AM than CM. Oxidative status, measured by plasma reactive oxygen metabolites and thiol groups, did not differ between MS throughout the whole lactation. These results suggest that early lactation of AM primiparous cows may give rise to crucial situations: for milk production, when a low MF may impair further mammary cell proliferation; for milk quality, if an irregular MF, with prolonged milking intervals, leads to an increased milk $\mathrm{pH}$ with increased conversion of $\mathrm{pl}$ to $\mathrm{Pl}$.

Key words: automatic milking, plasmin, plasminogen, milk electrolyte

\section{INTRODUCTION}

The automatic milking (AM) system represents an opportunity to achieve 2 goals: to relieve the farmer from the labor-intensive routine of the conventional milking (CM) parlor; to allow a voluntary increase in milking frequency (MF) of the cow, which has been associated with an increase of 2 to $8 \%$ of milk production for multiparous cows (Svennersten-Sjaunja and Pettersson, 2008). However, there are some cases in which the introduction of $\mathrm{AM}$ caused a reduction of $\mathrm{MF}$ and milk production (see review of Pirlo et al., 2005).

Automatic milking implies variability in MF, generally affected by several factors related to the cow (parity, DIM, health status) and management (Spolders et al., 2004). As a cascade, different MF within AM, also characterized by irregular milking intervals, may affect milk production (Abeni et al., 2005a; Bach and Busto, 2005; Speroni et al., 2006), milk quality (Abeni et al., 2005b), and some metabolic aspects (Abeni et al., 2005a).

There is abundant evidence that the rate of milk secretion is directly correlated with $\mathrm{MF}$, as a result of the mechanisms related to the local control of milk 
secretion (Knight et al., 1998). Long intervals between milkings have been reported to decrease mammary blood flow (Delamaire and Guinard-Flament, 2006a) and downregulate the udder's ability to extract nutrients from the blood (Delamaire and Guinard-Flament, 2006b).

In addition, MF acts through the effect of milking interval on the time available for plasminogen (pl) to be converted to plasmin ( $\mathbf{P l})$, resulting in an increased $\mathrm{pl}$ to $\mathrm{Pl}$ ratio changing from twice-daily $(2 \times)$ to thricedaily $(3 \times)$ milking (Sorensen et al., 2001). In healthy udders, $\mathrm{Pl}$ is the main endogenous protease, which, in turn, is formed in milk after specific cleavage of pl, its inactive zymogen derived from blood. The concentrations of both $\mathrm{pl}$ and $\mathrm{Pl}$ in milk increase as lactation progresses, due to increased activation of $\mathrm{pl}$ to $\mathrm{Pl}$ and also to greater leakage of $\mathrm{pl}$ from serum into milk (Stelwagen et al., 1994). The assessment of the effects of $\mathrm{AM}$ on $\mathrm{pl}$ and $\mathrm{Pl}$ activities is of particular concern for milk that must be transformed into typical Italian long ripening cheeses because they can reduce efficiency of transformation and product quality (Pirlo et al., 2004).

A common way of assessing paracellular permeability in the lactating mammary gland is to measure the solute content of milk; the concentration of lactose and $\mathrm{K}$ in milk decreases (moving down their concentration gradients), whereas those of $\mathrm{Na}$ and $\mathrm{Cl}$ increase when the junctions become leaky (Stelwagen et al., 1999; Shennan and Peaker, 2000; Boutinaud et al., 2003; Shamay et al., 2003; Delamaire and Guinard-Flament, $2006 b)$. With a study in which different MF $(2 \times$ vs. $3 \times)$ on half-udder of the same cows were adopted, Sorensen et al. (2001) concluded that mammary epithelial integrity (assessed by milk $\mathrm{Na}$ to $\mathrm{K}$ ratio) was greater in the half-udder that was milked $3 \times$.

Wiktorsson et al. (2003) investigated some physiologic and metabolic aspects of the cow in an AM system throughout the first 19 wk of lactation (WOL). They showed that primiparous cows may experience a severely negative energy balance in early lactation, with a greater body tissue mobilization than that of the multiparous cows, when a high MF occurs in the AM. Wenzel and Nitzschke (2004) compared CM and AM to study the effects on the incidence of ketosis, and they did not find any significant differences in serum glucose, BHBA, and urea. Abeni et al. (2005a) investigated plasma metabolites in primiparous cows in AM system compared with those in CM system and did not find any significant differences in milk production, BCS, and energy-related metabolites (glucose, NEFA, BHBA, and triglycerides) during the first 22 WOL.

Metabolism and environmental factors can cause oxidative stress as result of an imbalance between endogenous production of reactive oxygen metabolites
(ROM) and neutralizing capacity of antioxidant mechanisms. Plasma level of ROM is considered an indicator of free radical production (Bernabucci et al., 2005). The markers of oxidative status were chosen because they have all been implicated in the pathways that link oxidation to pathologic processes that may affect milk production, reproduction, and immunity (Bernabucci et al., 2005). Total thiol groups of plasma (SHp) represent the sulfhydryl groups of albumin, L-cysteine, and homocysteine; they are considered a significant element of the extracellular antioxidant defense system against oxidative stress and can be used to describe antioxidant potential in dairy cows (Bernabucci et al., 2005).

The hypothesis of increased variability in milk production due to the AM system, together with insufficient information on cow metabolic status from field trials adopting a forced traffic system, justifies monitoring energy-related metabolic aspects when $\mathrm{CM}$ and AM are compared.

The objective of this study was to compare the effects of the variation of MF related to the adoption of an AM system on cow mammary epithelial integrity and milk proteolytic enzymes during the first lactation. In addition, metabolic profile and oxidative status of the cows were monitored to assess possible interferences on the results of milk production and milk quality aspects.

\section{MATERIALS AND METHODS}

\section{Animals and Husbandry}

One cow from each of 6 pairs of twin Italian Friesian heifers was assigned to be milked with AM or with $\mathrm{CM}$ throughout first lactation. Two months before calving, heifers were scored for BCS, according to Edmonson et al. (1989). All of the heifers calved from March 15 to August 20, 2003; the longest interval between calvings within a twin pair was $12 \mathrm{~d}$. At the beginning of lactation, the animals were introduced into 2 similar herds, each composed of a total of 45 cows, which were similar for average milk production and parity.

Both herds were housed in the same free stall barn with cubicles. On one side of the barn there was an 8+8 herring-bone milking parlor; on the other side there was a single box AM system (DeLaval VMS, DeLaval, Tumba, Sweden). Both groups were fed with the same TMR distributed once daily (at $0800 \mathrm{~h}$ ). Cows in $\mathrm{AM}$ system also received a concentrate supply in the milking stall: $1 \mathrm{~kg} / \mathrm{d}$ every $10 \mathrm{~kg}$ of milk production, on average. This concentrate supplied in the milking stall had a chemical composition very similar to the TMR chemical characteristics (Table 1). Cows in CM received an addition of concentrate supplied with TMR 
Table 1. Average composition, chemical analysis, and nutritive value (\% of DM) of TMR fed to twins milked in a conventional milking parlor (CM) or in a single box automatic milking system (AM)

\begin{tabular}{|c|c|c|}
\hline Item & $\mathrm{CM}$ & $\mathrm{AM}^{1}$ \\
\hline \multicolumn{3}{|l|}{ Ingredient } \\
\hline Fescue hay & 8.6 & 9.6 \\
\hline Alfalfa hay & 7.8 & 7.2 \\
\hline Corn silage & 33.2 & 34.0 \\
\hline Cottonseed whole & 8.1 & 8.1 \\
\hline $\begin{array}{l}\text { Corn grain ( } 70 \% \text { ground and } \\
30 \% \text { steam flaked) }\end{array}$ & 22.2 & 21.1 \\
\hline Commercial protein concentrate ${ }^{2}$ & 19.2 & 19.1 \\
\hline Vitamin and mineral premix ${ }^{3}$ & 0.9 & 0.9 \\
\hline \multicolumn{3}{|l|}{ Nutrient } \\
\hline $\mathrm{CP}$ & 15.1 & 14.9 \\
\hline Ether extract & 4.78 & 4.77 \\
\hline NDF & 32.77 & 33.23 \\
\hline $\mathrm{ADF}$ & 20.26 & 20.71 \\
\hline Starch & 27.61 & 27.05 \\
\hline $\mathrm{NE}_{\mathrm{L}}, \mathrm{Mcal} / \mathrm{kg}$ of $\mathrm{DM}$ & 1.57 & 1.57 \\
\hline
\end{tabular}

${ }^{1}$ Cows in AM also received a concentrate supply in the milking stall ( $1 \mathrm{~kg} / \mathrm{d}$ every $10 \mathrm{~kg}$ of milk production, on average) and $1 \mathrm{~kg}$ of DM contained $177 \mathrm{~g}$ of CP, $37 \mathrm{~g}$ of ether extract, $292 \mathrm{~g}$ of NDF, $120 \mathrm{~g}$ of $\mathrm{ADF}$, and $245 \mathrm{~g}$ of starch.

${ }^{2} 1 \mathrm{~kg}$ contained $12 \mathrm{~g}$ of $\mathrm{Ca}, 7.8 \mathrm{~g}$ of $\mathrm{P}, 23 \mathrm{mg}$ of $\mathrm{Fe}, 6 \mathrm{mg}$ of $\mathrm{Cu}, 110 \mathrm{mg}$ of Mn, $0.3 \mathrm{mg}$ of Co, $165 \mathrm{mg}$ of Zn, $0.9 \mathrm{mg}$ of I, $0.02 \mathrm{mg}$ of Se, 45,000 IU of vitamin A, 2,000 IU of vitamin $\mathrm{D}_{3}$, and $65 \mathrm{mg}$ of vitamin $\mathrm{E}$.

${ }^{3} 1 \mathrm{~kg}$ contained $145 \mathrm{~g}$ of $\mathrm{Ca}, 70 \mathrm{~g}$ of $\mathrm{P}, 1,350 \mathrm{mg}$ of $\mathrm{Fe}, 400 \mathrm{mg}$ of $\mathrm{Cu}$, $2,500 \mathrm{mg}$ of Mn, $50 \mathrm{mg}$ of Co, $500 \mathrm{mg}$ of $\mathrm{Zn}, 115 \mathrm{mg}$ of I, $20 \mathrm{mg}$ of Se, $1,000,000 \mathrm{IU}$ of vitamin A, 150,000 IU of vitamin $\mathrm{D}_{3}, 5,000 \mathrm{mg}$ of vitamin $\mathrm{E}$.

that, ranging between 0.5 to $1.5 \mathrm{~kg} / \mathrm{d}$ at the planned DMI level for the primiparous animals of the 2 groups, achieved a balance in average energy and protein intake in the 2 herds (Table 1). Routine milking times in the parlor started at $0530 \mathrm{~h}$ and at $1630 \mathrm{~h}$. Ingredients of the TMR in both groups are reported in Table 1.

In the AM system area, selectively forced cow traffic (as defined by Harms et al., 2002) was applied. The feeding area was separated from the resting area by 1-way gates, which allowed the cow free access to the cubicles without being milked. However, they were obliged to pass the AM area before entering the feeding area, with a bypass consisting of a preselection gate: cows that had recently been milked (less than $5 \mathrm{~h}$, with the exception of passages after an incomplete milking) did not have to pass the milking stall and the waiting area in front of it and were deviated directly to the feeding area, whereas the others were admitted to the milking stall. The layout of our barn with AM was reported in Abeni et al. (2005a). The AM system was always accessible except during cleaning at 0400, 1200, and $2000 \mathrm{~h}$ for about 30 min each time. Twice a day (0530 and 1730 $\mathrm{h}$ ), any cow that had not been milked during the last 12 $\mathrm{h}$ was fetched to the AM unit to avoid milking intervals greater than $12 \mathrm{~h}$. Health disorders of each heifer were recorded and classified during the trial.
Milk production was recorded continuously with AM, using a daily mean calculated on 4 consecutive days as representative of a week for statistical analysis, whereas milk production of cows with CM was recorded weekly (for 2 consecutive milkings). Data on traffic of each twin cow with AM were obtained from the recorded passages through the preselection gate and in the milking unit.

\section{Sampling}

Blood samples were obtained before the morning distribution of TMR, at $0730 \mathrm{~h}$. The bleeding moment, with respect to calving date, was $-14,1,7,14,28,42,70,98$, 154,210 , and $266 \mathrm{~d}$. With the same schedule, BCS was evaluated on each heifer. A single blood sample was collected from the jugular vein via venipuncture, using $10-\mathrm{mL} \mathrm{Li}$-heparin Venoject tubes (Terumo Europe, Leuven, Belgium). Blood samples were immediately placed in an ice bath, where they were stored until they were processed, within approximately $30 \mathrm{~min}$ from withdrawal. Packed cell volume was determined using a hematocrit centrifuge; then, plasma was separated by centrifugation $(2,850 \times \mathrm{g}$ for $20 \mathrm{~min})$, and 4 subsamples were stored immediately at $-20^{\circ} \mathrm{C}$ until analyzed.

Milk production in CM system was recorded weekly for 2 consecutive milkings throughout the trial; milk production in AM system was automatically recorded by the system, and the mean of 4 consecutive days was calculated as representative of each WOL; milk samples were collected at 4, 11, 18, 25, 32, and 39 WOL.

\section{Laboratory Analyses}

Feedstuffs were analyzed for dry matter, CP, crude fiber, NDF, ether extract, ash, and starch content (Martillotti et al., 1987). The values of $\mathrm{NE}_{\mathrm{L}}$ were estimated according to NRC (2001).

The blood metabolites were analyzed at $37^{\circ} \mathrm{C}$ by a clinical analyzer (ILAB 650 photometer, Instrumentation Laboratory, Lexington, MA). The plasma glucose, urea, cholesterol, and triglyceride concentrations were determined using commercial kits (IL Test Kit reagent, Instrumentation Laboratory). In detail, the plasma levels of glucose and cholesterol were determined by a bichromatic analysis; the plasma levels of urea and triglycerides were determined by a kinetic fixed time analysis. The plasma levels of NEFA were determined by an enzymatic-colorimetric test (C-Test Wako, Wako Chemicals GmbH, Neuss, Germany). Plasma levels of SHp and ROM were run with colorimetric methods (Diacron, Grosseto, Italy). 
Table 2. Results from ANOVA of milk production, BCS, and blood metabolites according to milking system $(\mathrm{CM}=$ conventional milking parlor; $\mathrm{AM}=$ automatic milking system), and significance of the factors with the selected model

\begin{tabular}{|c|c|c|c|c|c|c|c|}
\hline Item & \multicolumn{2}{|c|}{$\mathrm{CM}$} & \multicolumn{2}{|c|}{$\mathrm{AM}$} & \multicolumn{3}{|c|}{$P$-value } \\
\hline BCS, score & 2.92 & 0.04 & 2.91 & 0.04 & NS & 0.007 & NS \\
\hline Packed cell volume (PCV), L/L & 0.314 & 0.005 & 0.312 & 0.005 & NS & 0.136 & NS \\
\hline Plasma glucose, mmol/L & 3.861 & 0.085 & 3.625 & 0.083 & 0.073 & NS & NS \\
\hline Plasma urea, $\mathrm{mmol} / \mathrm{L}$ & 3.746 & 0.159 & 3.858 & 0.155 & NS & 0.001 & 0.102 \\
\hline Plasma NEFA, $\mathrm{mmol} / \mathrm{L}$ & 0.366 & $0.291-0.461$ & 0.387 & $0.309-0.484$ & NS & 0.013 & $\mathrm{NS}$ \\
\hline Plasma NEFA/total cholesterol, ratio & 0.133 & 0.018 & 0.185 & 0.018 & 0.048 & $<0.0001$ & NS \\
\hline Plasma ROM ${ }_{2}^{4} \mathrm{mg}$ of $\mathrm{H}_{2} \mathrm{O}_{2} / 100 \mathrm{~mL}$ & 12.45 & 0.30 & 12.52 & 0.30 & NS & NS & NS \\
\hline Plasma SHp ${ }^{5} \mu \mathrm{mol} / \mathrm{L}$ & 213.8 & 10.2 & 207.0 & 10.2 & NS & 0.002 & NS \\
\hline
\end{tabular}

${ }^{1} \mathrm{SE}$ or CI = standard error was reported for normally distributed variables, whereas confidence interval (95\%) was reported for those variables that were processed with ANOVA after a log-transformation.

${ }^{2} \mathrm{MS}=$ milking system.

${ }^{3} \mathrm{WOL}=$ week of lactation.

${ }^{4} \mathrm{ROM}=$ reactive oxygen metabolites.

${ }^{5} \mathrm{SHp}=$ plasma thiol groups.

Milk fat and protein content were determined with a Fourier-transform infrared analyzer (Milkoscan FT 6000, Foss Electric, Hillerød, Denmark); SCC was determined with a flow cytometry instrument (Fossomatic 5000, Foss Electric). Milk pH was determined immediately after sampling (Crison Instruments, Alella, Spain). All milk samples were assessed for Pl and $\mathrm{pl}$ activities. In detail, the determination of $\mathrm{Pl}$ was performed in duplicate in 96-well microtiter plates containing $220 \mu \mathrm{L}$ of $0.1 M$ Tris-HCl buffer (pH 7.4), 0.6 $\mathrm{m} M$ of D-Val-Leu-Lys-4-nitroanilide (VAL, chromogenic substrate), and $30 \mu \mathrm{L}$ of sample. The assay for pl was carried out accordingly, but 30 plough units of urokinase were added to the reaction mixture to achieve complete activation of the proenzyme. In all cases, 3 wells in which samples were replaced by buffers that served as blanks to detect spontaneous breakdown of the substrate. Reaction mixtures were incubated at $37^{\circ} \mathrm{C}$ for $3 \mathrm{~h}$, and absorbance at $405 \mathrm{~nm}$ was read at 30-min intervals with a microplate reader (DV 990 BV 4/6, Gio De Vita \& Co., Rome, Italy). The rate of nitroanilide formation was measured from the linear portion of the absorbance vs. time curve. Plasminogen activity was calculated as the difference between total activity and $\mathrm{Pl}$ activity. Plasmin and $\mathrm{pl}$ activities were expressed as units, one unit being the amount of enzyme that produces a change in absorbance at $405 \mathrm{~nm}$ of 0.1 in $60 \mathrm{~min}$. The chromogenic substrate was purchased from Sigma Chemical Co. (St. Louis, MO); urokinase was from ICN (ICN Biomedicals Inc., Aurora, OH); all other reagents were of analytical grade purity. Milk concentrations of $\mathrm{Na}, \mathrm{K}$, and $\mathrm{Cl}$ were determined us- ing an indirect potentiometric method by ion-selective electrodes.

\section{Statistical Analysis}

Normal distribution of blood and milk variables was tested with the Shapiro-Wilk test before further analyses; therefore, not-normally distributed variables were log-transformed to obtain a normal distribution of the values for their submission to ANOVA. The experiment was a randomized block design, with milking system (MS; AM vs. CM), WOL, and MS $\times$ WOL as main factors, with cow repeated in time. The MIXED procedure of SAS (SAS Inst. Inc., Cary, NC) was used, with the prepartum control as a covariate (only for BCS and blood data). The cow nested within MS $\times$ WOL was used as the subject for the test of fixed effects. A first order autoregressive (AR1) structure of covariance was selected based on the results from fit statistics Akaike's information criteria and Bayesian information criteria. Least squares means and SE are reported in figures for the selected variables. For not-normally distributed variables, back-transformed values were presented in tables and figures, and CI instead of SE was considered as a dispersion index. If a significant $F$-test was detected $(P<0.05)$, interactions were evaluated using the PDIFF option in SAS and also highlighted in figures when $P<0.05$; a trend in data was considered when $P$ $<0.10$.

The same statistical procedure was used in milk production data analysis, the only difference being a greater number of observations in time and without 


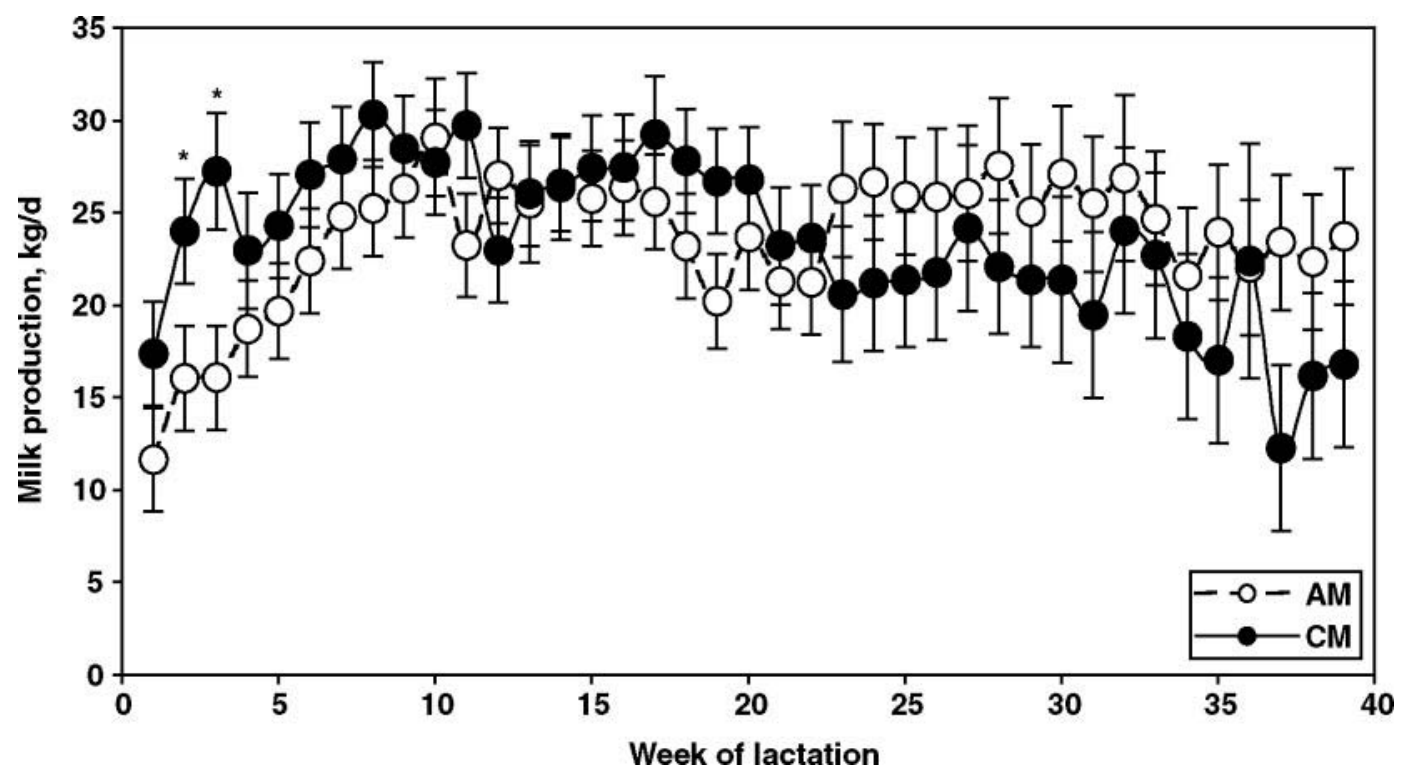

Figure 1. Daily milk production in the conventional milking system (CM) and in the automatic milking (AM) system throughout the experimental period of $39 \mathrm{wk}$. Data represent least squares means \pm SEM. The asterisks indicate that means within week of lactation differed for $P<0.05$.

covariate in the model. Milking frequency in the AM was analyzed by the same statistical procedure using a model considering only WOL as main effect; the same model and a model with only an intercept (Gygax et al., 2007) were performed using milking frequency minus 2 as a dependent variable to test whether the MF in the AMS differed from the constant predefined value in CM. Simple correlations among milk features were calculated and, where significant $(P<0.05)$, were reported in the text.

\section{RESULTS}

\section{Milk Production, Milking Frequency, and Plasma Metabolites}

The main statistics output on milk production, BCS, and blood features is shown in Table 2. The overall milk production was not affected by MS, but milk production at 2 and 3 WOL was lesser in AM than in CM (Figure 1).

The average milking frequency in the AM was 2.69 \pm 0.6 , and it was different from $2(P<0.05)$. However, it showed a pattern throughout lactation: the average milking frequency minus 2 for 1 to $4 \mathrm{WOL}, 5$ to $11 \mathrm{WOL}$, 6 to $18 \mathrm{WOL}, 19$ to $25 \mathrm{WOL}, 26$ to $32 \mathrm{WOL}$, and 33 to 39 WOL is shown in Figure 2. The same figure shows the absence of difference in MF between MS during the first month of lactation and, in the remaining part of lactation, a greater MF with AM than with CM.
Body reserves mobilization, as monitored by BCS, was not affected by MS and its interaction with WOL (Figure 3). There was a trend for lesser values of plasma glucose concentration in AM cows compared with CM cows $(P<0.10$; Table 2$)$, and this was primarily due to the lesser plasma glucose $(P<0.05)$ in AM at 2 and 4 WOL (Figure 4). Plasma urea did not differ between MS, but lesser values $(P<0.05)$ were detected in AM at 2 WOL (Figure 4). The AM cows had lesser plasma total cholesterol $(P<0.05$; Table 2$)$ and a greater NEFA/ total cholesterol ratio $(P<0.05$; Table 2 and Figure 5) throughout the first $14 \mathrm{WOL}$; however, this ratio was affected by the greater values in AM than in CM $(P<$ 0.05; Figure 5) in the first WOL.

The oxidative status of the cows was not affected by MS (Table 2$)$. There was a trend $(P<0.10)$ toward lesser values of ROM in AM at 2 WOL, but an opposite trend $(P<0.10)$ was observed at 22 WOL (Figure 6). Plasma SHp were affected only by WOL $(P=0.002$; Figure 6).

\section{Milk Features}

The main statistics output on milk features is shown in Table 3. Fat and protein contents, and somatic cell count did not differ between milking systems. Milk $\mathrm{pH}$ was greater $(P=0.05)$ in AM cows; particularly at 4 ( $P$ $=0.037)$ and at $25(P=0.058)$ WOL, milk pH in AM cows showed greater values than in CM cows (Figure 7). There were no effects of MS and MS $\times$ WOL on milk 


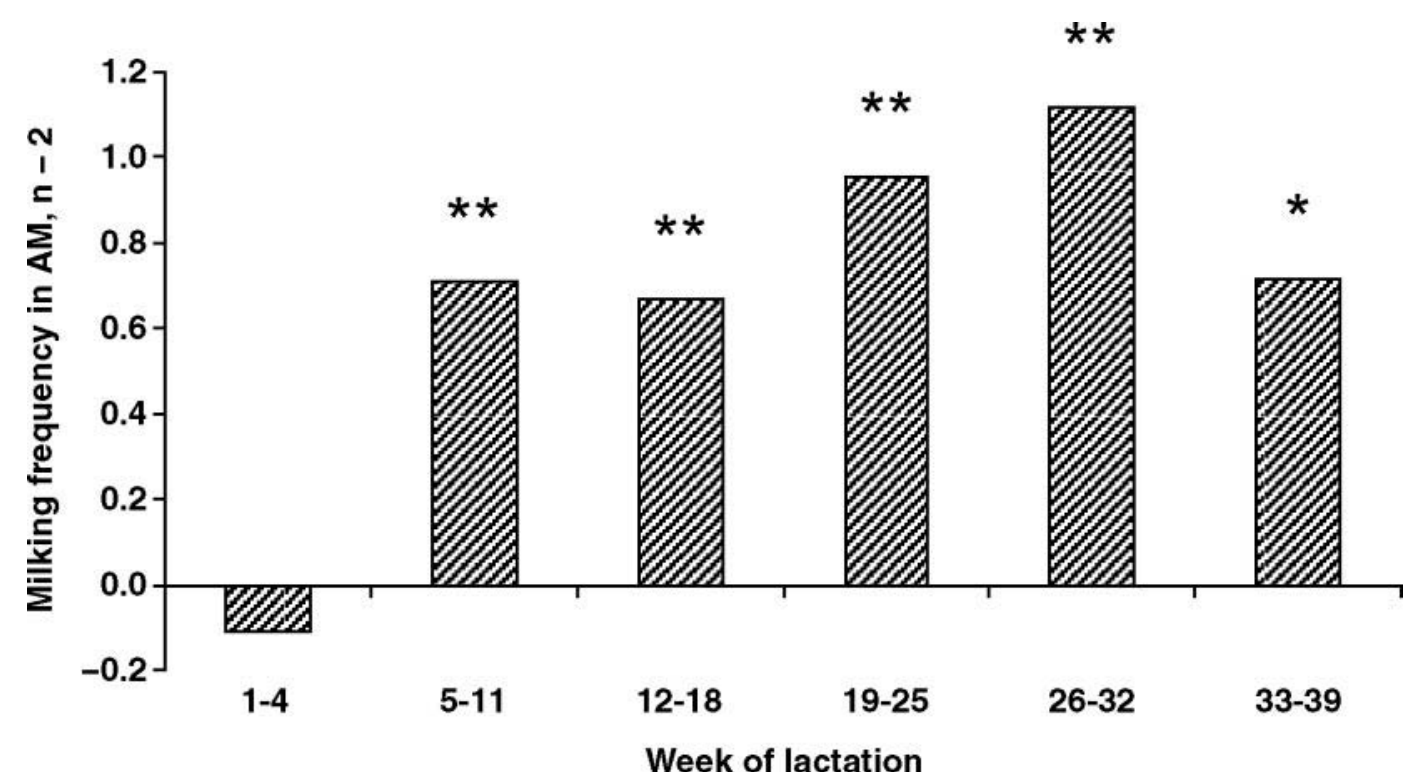

Figure 2. Differences between milking frequency in the automatic milking (AM) system and the conventional milking (CM) system in each period before milk sampling. Data represent least squares means (pooled SEM $=0.161$ ). The asterisks indicate that mean within period differed from 0 for $P<0.05(*)$ and $P<0.01(* *)$.

$\mathrm{Na}, \mathrm{K}$, and $\mathrm{Cl}$ contents and on milk $\mathrm{Na} / \mathrm{K}$ ratio (Table 3); however, at $4 \mathrm{WOL}$, the AM milk had a trend for greater $\mathrm{Na}(P<0.10$; Figure 7$)$ and $\mathrm{Cl}(P=0.055$; Figure 7) contents than CM milk.

Both pl (Figure 8) and total activity $(\mathrm{pl}+\mathrm{Pl}$ ) were lesser $(P<0.01$; Table 3$)$ in AM than in CM milk. The AM milk at 4 WOL had lesser $(P=0.003$; Figure 8$)$ pl and greater $(P=0.010$; Figure 8$) \mathrm{Pl}$, which resulted in a lesser $(P=0.001) \mathrm{pl} / \mathrm{Pl}$ ratio than $\mathrm{CM}$ milk (Figure 8).

Milk $\mathrm{pH}$ had a positive correlation with milk $\mathrm{Pl}(\mathrm{r}=$ $0.41 ; P=0.004), \mathrm{Na}(\mathrm{r}=0.37 ; P=0.007)$, and $\mathrm{Cl}(\mathrm{r}=$ $0.40 ; P=0.003)$ concentration and a negative correlation with the $\log _{10}$ of $\mathrm{pl} / \mathrm{Pl}$ ratio $(\mathrm{r}=-0.47 ; P<0.001)$. The milk Na/K ratio had a stronger positive $(\mathrm{r}=0.55 ; P$ $<0.0001)$ correlation with milk $\mathrm{Pl}$ activity.

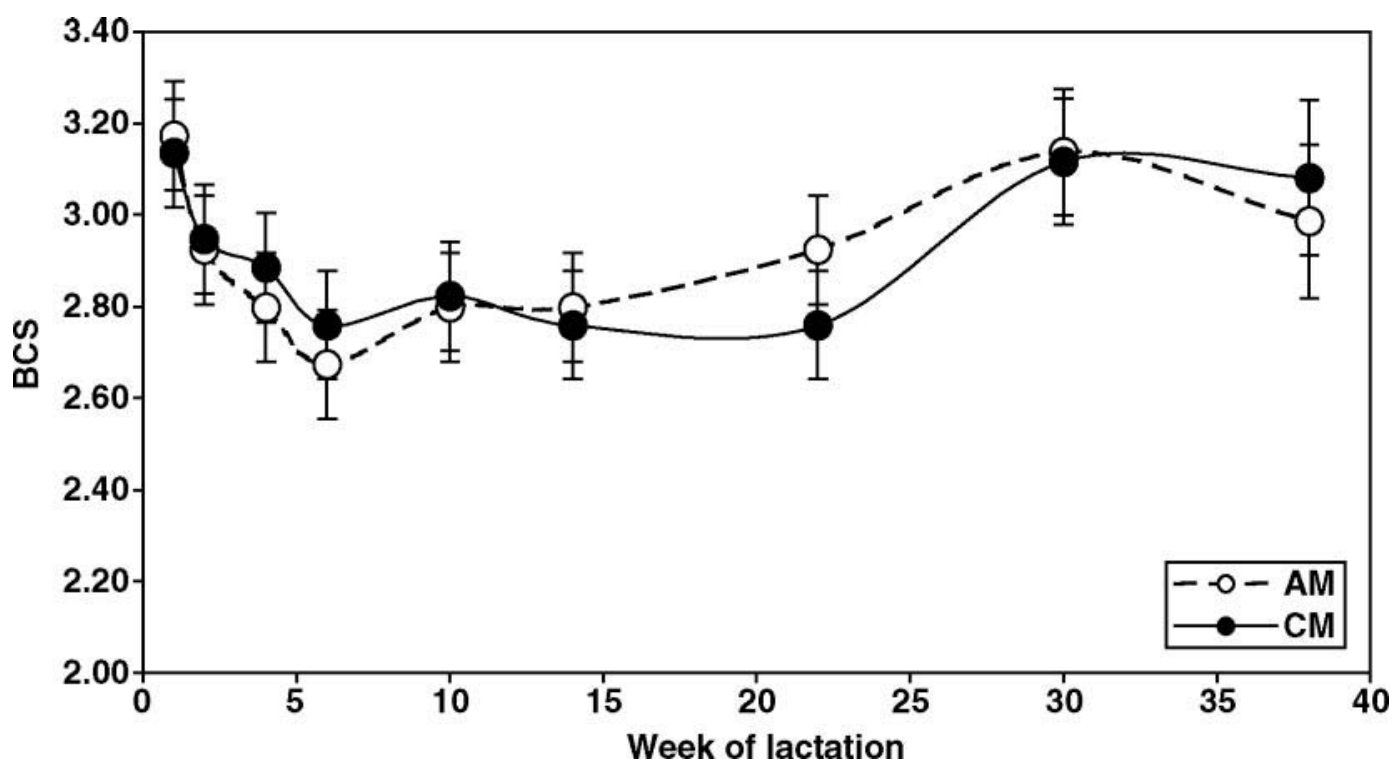

Figure 3. Body condition score in the conventional milking system (CM) and in the automatic milking (AM) system throughout the experimental period of $39 \mathrm{wk}$. Data represent least squares means $\pm \mathrm{SEM}$. 

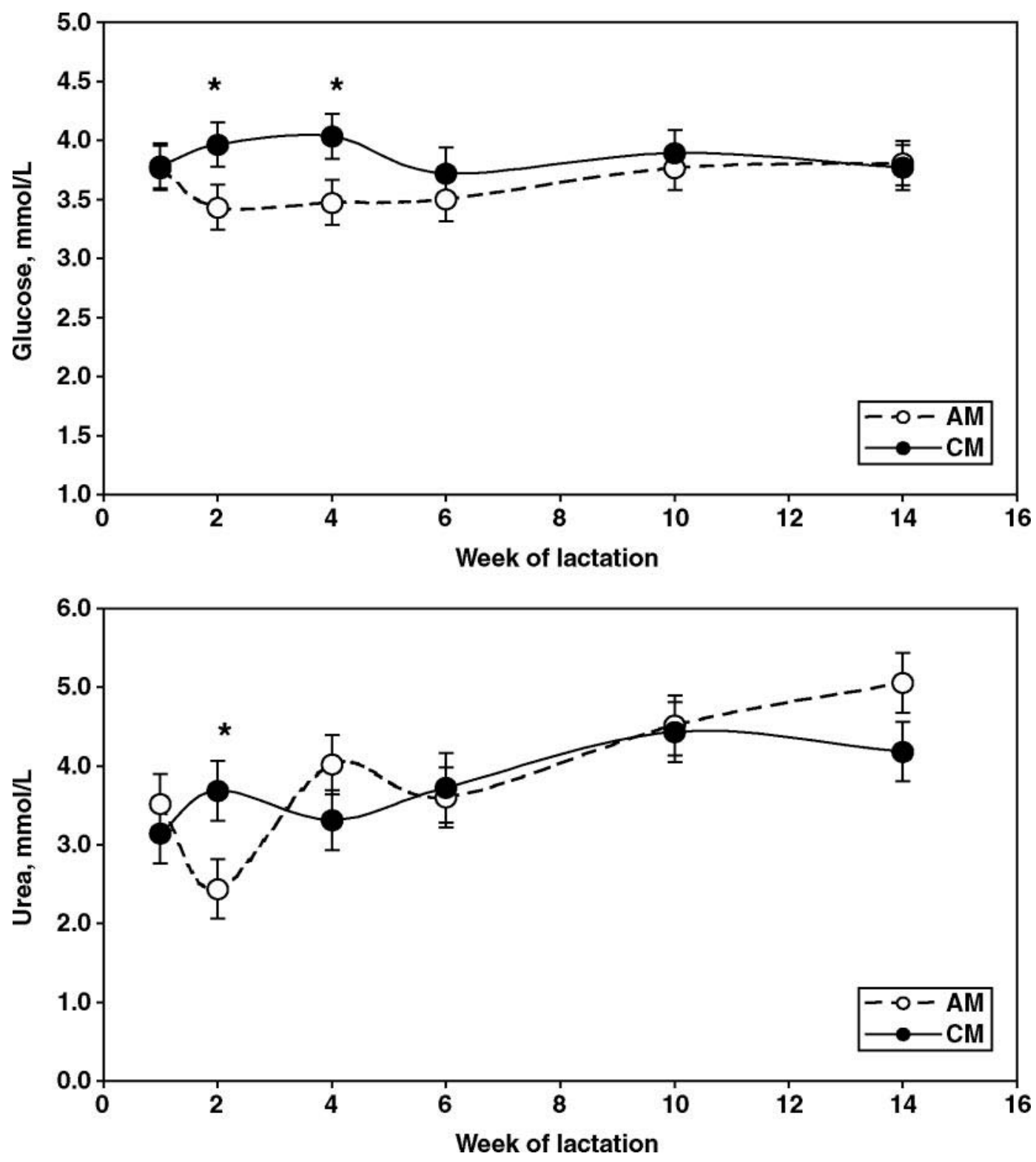

Figure 4. Plasma concentrations of glucose and urea in the conventional milking system (CM) and in the automatic milking (AM) system throughout the first $14 \mathrm{wk}$ of lactation. Data represent least squares means \pm SEM. The asterisks indicate that means within period differed for $P<0.05$.

\section{DISCUSSION}

\section{Milk Production, Milk Composition, Plasma} Metabolites, and Oxidative Status

Milk Production and Milking Frequency. In a previous study (Speroni et al., 2006), we observed increased milk production in pluriparous cows with AM, not confirmed in primiparous cows, when compared with those with CM. Even in the present study, milk production of primiparous cows was unaffected by MS, confirming our previous results (Abeni et al., 2005a; Speroni et al., 2006). Generally, increased MF with CM systems, especially during early stage of lactation, led to increased milk production (Hale et al., 2003; Dahl et al., 2004). Hale et al. (2003) reported that milk productions were $34.5,37.8$, and $37.6 \mathrm{~kg} / \mathrm{d}$ from 1 to $44 \mathrm{WOL}$ for $2 \times, 4 \times$ during the first 21 DIM followed by $2 \times$, and $4 \times$ from 4 to $21 \mathrm{DIM}$ followed by $2 \times$, respectively. That study suggested that the increase of MF in the first 3 WOL was sufficient to elicit a carryover effect on milk production that continued into late lactation. That response seemed mainly attributable to an increased mammary cell proliferation during increased MF in early lactation (Hale et al., 2003). 


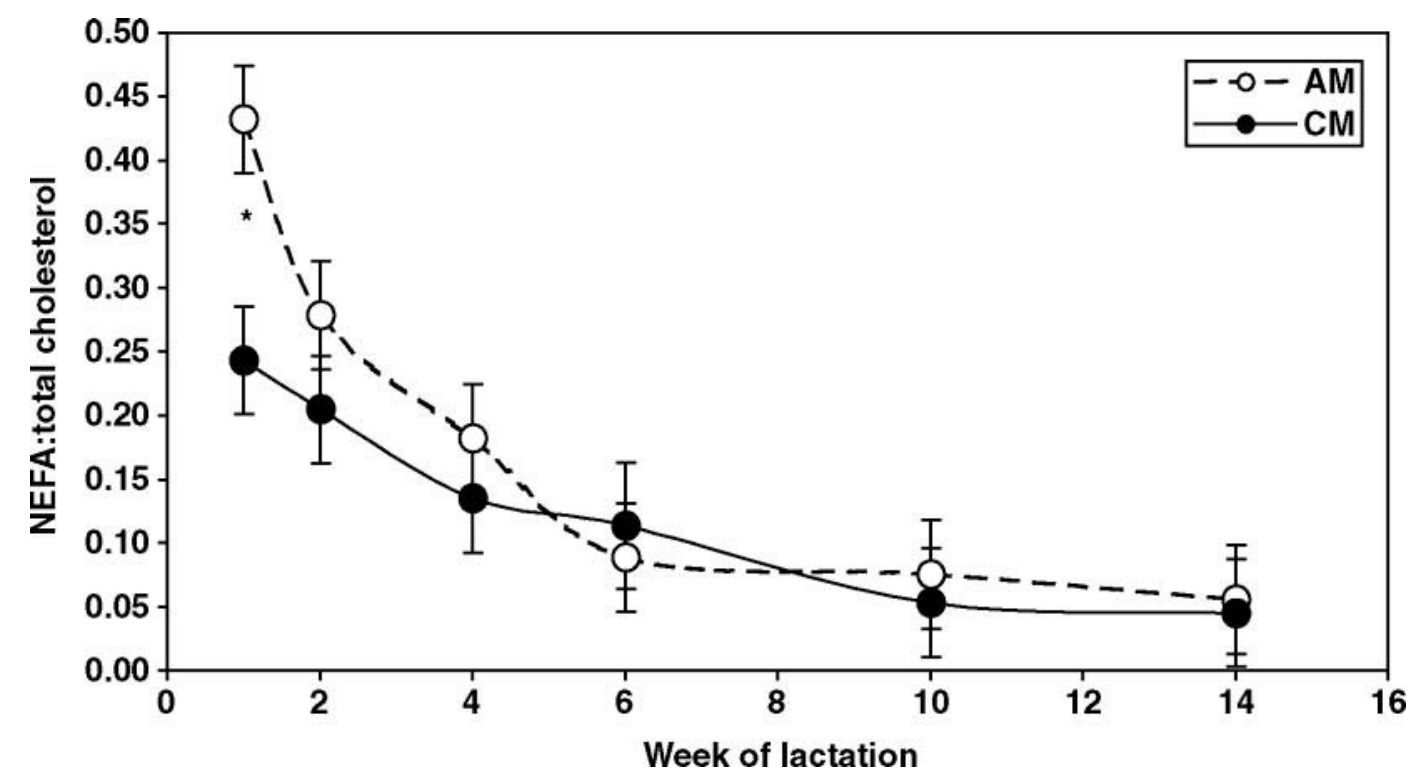

Figure 5. Plasma NEFA/total cholesterol ratio in the conventional milking system (CM) and in the automatic milking (AM) system throughout the first $14 \mathrm{wk}$ of lactation. Data represent least squares means \pm SEM. The asterisks indicate that means within period differed for $P<0.05$.

A possible explanation for the results of our trial could be that early lactation of AM cows may have impaired the potential production by an irregular or low MF, or both, probably limiting the above-mentioned mammary cell proliferation potential (Hale et al., 2003). This issue should be taken into consideration for correct management and traffic surveillance of primiparous cows when they start to be milked in an AM system.

Milk Composition. Fat and protein contents and SCC did not differ between MS, substantially confirming our previous observations on primiparous cows (Abeni et al., 2005b).

Milk SCC was found to be unaffected by MF both when once-daily $(1 \times)$ vs. $2 \times($ Lacy-Hulbert et al., 1999) and when $1 \times$ vs. $3 \times($ Patton et al., 2006) milking were compared. Cows milked $6 \times$ had lesser SCC at first test day relative to those milked $3 \times$ (Dahl et al., 2004). That difference was reflected also in reduced somatic cell scores for the first 3 mo of lactation, suggesting that MF in early lactation influences the mammary gland capacity to resist infection in addition to improving milk production efficiency (Dahl et al., 2004). In the present study, udder health appeared similar between groups, and it is possible to exclude possible interferences on mammary epithelial permeability evaluation.

Plasma Metabolites and Oxidative Status. Despite a low milk production level in the first month of lactation, AM cows had lesser plasma glucose and greater plasma NEFA/cholesterol ratio than CM cows. These traits of metabolic profile suggest a slight difficulty on the part of AM primiparous cows in coping with their productive performance in early lactation. The greater NEFA/cholesterol ratio in AM than CM cows is a warning of an increased risk of developing metabolic disorders (i.e., fatty liver) when liver ability to export triglycerides does not match body fat mobilization (Drackley et al., 2005). A possible explanation for greater plasma NEFA in AM cows could be seen in the daily feeding behavior of primiparous cows within an AM herd, with longer feeding intervals for AM primiparous than CM primiparous at the sampling moment in the morning (Abeni et al., 2005a). Ketelaar-de Lauwere et al. (1998) emphasized that during forced cow traffic cows spent more time standing on the slatted floor in the feeding area, spent less time standing at the feeding gate and made fewer journeys from the lying to the feeding area. Thus, a reduced or irregular feeding activity (as arguable from Figure 2) may distress some difficulties of primiparous cows in matching their nutrient requirements, especially in early stage of lactation. The lack of differences in plasma urea and triglycerides in the present paper confirms our previous results (Abeni et al., 2005a) and agree with those of Patton et al. (2006) with different MF.

The ROM level confirmed our previous results (Calza et al., 2005) about a trend toward lesser oxidative stress in AM at an early stage of lactation, but also a trend toward greater ROM levels in AM than CM in mid to late lactation. The explanation of this result does not seem attributable, in our trial, to differences in body reserves mobilization (Bernabucci et al., 2005). The opposite pattern of ROM values in AM compared with 

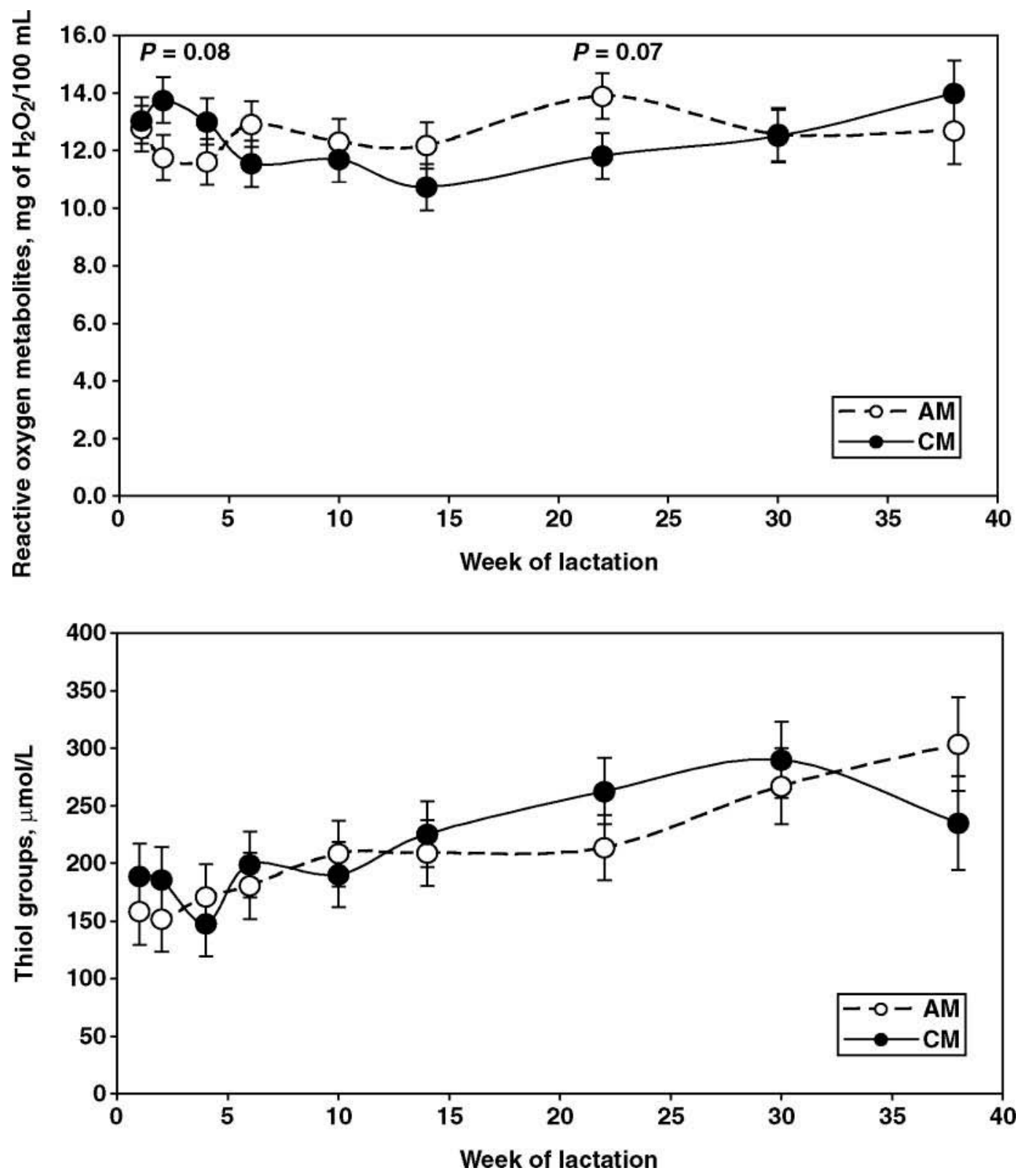

Figure 6. Plasma concentrations of reactive oxygen metabolites and thiols in the conventional milking system (CM) and in the automatic milking (AM) system throughout the first 14 wk of lactation. Data represent least squares means \pm SEM.

that of CM suggests a relatively reduced metabolic stress in early lactation for AM, but the nature of the successive increase throughout AM lactation requires further investigation.

\section{Mammary Epithelial Permeability and Proteolytic Enzymes Activity in Milk}

The present study demonstrated that milk $\mathrm{pH}$ was greater $(P<0.05)$ with $\mathrm{AM}$, but milk $\mathrm{Na}, \mathrm{K}, \mathrm{Na} / \mathrm{K}$ ratio, and $\mathrm{Cl}$ did not differ across whole lactation. A similar increase in individual milk $\mathrm{pH}$ in $\mathrm{AM}$ primiparous cows, compared with that of primiparous cows in CM, has already been observed in a previous trial at our experimental farm (Pirlo et al., 2004). From our results, the increased milk $\mathrm{pH}$ does not seem attributable to a different MF per se because milk $\mathrm{pH}$ was greater in $\mathrm{AM}$ even when MF was low (as observed in the first month of lactation). A possible explanation should be sought in the irregularity of milking interval within AM systems, this being the only constant feature of AM even when its MF was lesser, equal, or greater than CM 
Table 3. Results from ANOVA of milk features according to milking system $(\mathrm{CM}=$ conventional milking parlor; $\mathrm{AM}=$ automatic milking system), and significance of the factors with the selected model

\begin{tabular}{|c|c|c|c|c|c|c|c|}
\hline \multirow[b]{2}{*}{ Item } & \multicolumn{2}{|c|}{$\mathrm{CM}$} & \multicolumn{2}{|c|}{$\mathrm{AM}$} & \multicolumn{3}{|c|}{$P$-value } \\
\hline & Mean & $\mathrm{SE}$ or $\mathrm{CI}^{1}$ & Mean & $\mathrm{SE}$ or $\mathrm{CI}^{1}$ & $\mathrm{MS}^{2}$ & $\mathrm{WOL}^{3}$ & $\mathrm{MS} \times \mathrm{WOL}$ \\
\hline Protein content, \% vol $/ \mathrm{vol}$ & 3.37 & 0.10 & 3.33 & 0.09 & NS & NS & NS \\
\hline $\mathrm{SCC}, 1,000$ cells $/ \mathrm{mL}$ & 201 & $78-516$ & 143 & 54-377 & NS & NS & NS \\
\hline Milk pH & 6.674 & 0.015 & 6.715 & 0.014 & 0.05 & 0.049 & NS \\
\hline $\mathrm{Na}, \mathrm{mEq} / \mathrm{L}$ & 22.25 & $20.10-24.64$ & 22.15 & $20.26-24.21$ & NS & NS & NS \\
\hline $\mathrm{Cl}, \mathrm{mEq} / \mathrm{L}$ & 17.75 & 15.65-20.13 & 18.68 & $16.73-20.85$ & $\mathrm{NS}$ & NS & NS \\
\hline Plasminogen, units & 31.43 & 1.63 & 23.95 & 1.49 & 0.002 & 0.001 & NS \\
\hline Plasmin, units & 5.03 & $3.68-6.88$ & 4.90 & $3.70-6.50$ & NS & NS & 0.126 \\
\hline Plasminogen/plasmin, ratio & 5.83 & $4.10-8.30$ & 4.43 & $3.23-6.09$ & NS & 0.019 & 0.044 \\
\hline Total activity, ${ }^{4}$ units & 37.23 & 1.84 & 30.40 & 1.69 & 0.009 & 0.020 & NS \\
\hline
\end{tabular}

${ }^{1} \mathrm{SE}$ or $\mathrm{CI}=$ standard error was reported for normally distributed variables, whereas confidence interval (95\%) was reported for those variables that were processed with ANOVA after a log-transformation.

${ }^{2} \mathrm{MS}=$ milking system.

${ }^{3} \mathrm{WOL}=$ week of lactation.

${ }^{4}$ Total activity $=$ plasminogen + plasmin activity.

system. Our results evidenced greater milk $\mathrm{pH}$ in $\mathrm{AM}$ at $4 \mathrm{WOL}$, together with a trend for greater milk $\mathrm{Na}$ and $\mathrm{Cl}$ contents. During this stage, primiparous cows in AM had great variability in milking interval length, in some cases greater than $12 \mathrm{~h}$ (Abeni et al., 2005a). Lacy-Hulbert et al. (1999) emphasized increased milk $\mathrm{pH}$ and $\mathrm{Na}$ content with $1 \times$ compared with $2 \times$ milking. The relationships among milk $\mathrm{Na}$ and $\mathrm{Cl}$ contents and milk $\mathrm{pH}$, in the present study also lead one to hypothesize changes in ionic equilibrium not affected by udder health, which was always good in all the cows involved.

Milking system did not affect mammary epithelial permeability throughout $39 \mathrm{WOL}$, as attested by $\mathrm{Na}$, $\mathrm{K}$, and $\mathrm{Cl}$ milk content, and by $\mathrm{Na} / \mathrm{K}$ ratio in milk. As reported by Sorensen et al. (2001), who compared $2 \times$ vs. $3 \times$, the $\mathrm{Na} / \mathrm{K}$ ratio was inversely correlated with mammary epithelial integrity, and this ratio increased throughout the course of lactation and was always greater in $2 \times$ (Sorensen et al., 2001). The Na concentration in milk is normally lesser than in plasma due to the presence of Na pumps only on the basolateral aspect of the secretory cell (Shennan and Peaker, 2000). An increase in the $\mathrm{Na} / \mathrm{K}$ ratio is thus indicative of leaky tight junctions, allowing partial equilibration between plasma and milk (Sorensen et al., 2001).

Both $\mathrm{pl}$ and $\mathrm{pl}+\mathrm{Pl}$ activities were lesser $(P<0.05)$ in AM. Plasmin activity was also associated with major casein components and milk $\mathrm{pH}$ (Politis et al., 1989). The correlation reported between milk $\mathrm{pH}$ and milk $\mathrm{Pl}$ activity $(r=0.41)$, in the present paper, was greater than that $(r=0.19)$ previously indicated by Politis et al. (1989). Plasminogen activators are present in milk and have a $\mathrm{pH}$ optimum of 7.8 (Politis et al., 1989). Higher $\mathrm{pH}$ values could increase conversion of $\mathrm{pl}$ to $\mathrm{Pl}$ with a resultant increase in proteolysis. Schaar (1985) reported a tendency for greater proteolytic activity with increasing milk $\mathrm{pH}$ (Politis et al., 1989). All of these considerations may be involved in the explanation of the high $\mathrm{Pl}$ activity and, as a consequence, the low $\mathrm{pl} / \mathrm{Pl}$ ratio at $4 \mathrm{WOL}$ in $\mathrm{AM}$ in the present study, when the greater milk $\mathrm{pH}$ in AM has probably led to an increased conversion of $\mathrm{pl}$ to $\mathrm{Pl}$. In fact, one effect of increased $\mathrm{MF}$ is to reduce the time available for $\mathrm{pl}$ to be converted to Pl; Sorensen et al. (2001) observed an increased $\mathrm{pl} / \mathrm{Pl}$ from 3.40 to 6.16 changing from $2 \times$ to 3 $\times$. In the same study, $\mathrm{pl}$ concentration decreased with MF increase, suggesting that influx had been reduced, which is exactly what one would predict if uptake was passive through tight junctions that had become tighter (Sorensen et al., 2001). In our trial, the decrease in pl activity was significant in AM and was comparable with that obtained by Sorensen et al. (2001), who reported a reduction in pl activity from 42.69 to 35.43 units, changing from $2 \times$ to $3 \times$ (Sorensen et al., 2001).

The strong positive correlation $(\mathrm{r}=0.55 ; P<0.0001)$ in milk between $\mathrm{Na} / \mathrm{K}$ ratio and $\mathrm{Pl}$ activity confirms the importance of the blood/milk barrier integrity in the prevention of enzymatic proteolytic activities in milk. The influx of a large number of blood components in milk has a positive effect on $\mathrm{Pl}$ activity, first by the increase of the $\mathrm{pl}$ concentration (Le Roux et al., 2003). In addition, other blood components with a main action other than $\mathrm{pl}$ activation do have an effect on $\mathrm{pl}$ conversion into Pl: epidermal growth factor, IGF-I, and prostaglandin E2, as suggested by Le Roux et al. (2003). 
The differences in enzymatic (proteolytic) activity between MS, probably related to daily MF, lead to the supposition that the quality of the protein fraction for the cheese-making process was preserved better with $\mathrm{AM}$ than with $\mathrm{CM}$, even if differences in $\mathrm{pH}$ might negatively interfere.

\section{CONCLUSIONS}

Although AM is generally considered to increase milk production, this effect was not confirmed in the present study, probably because primiparous cows
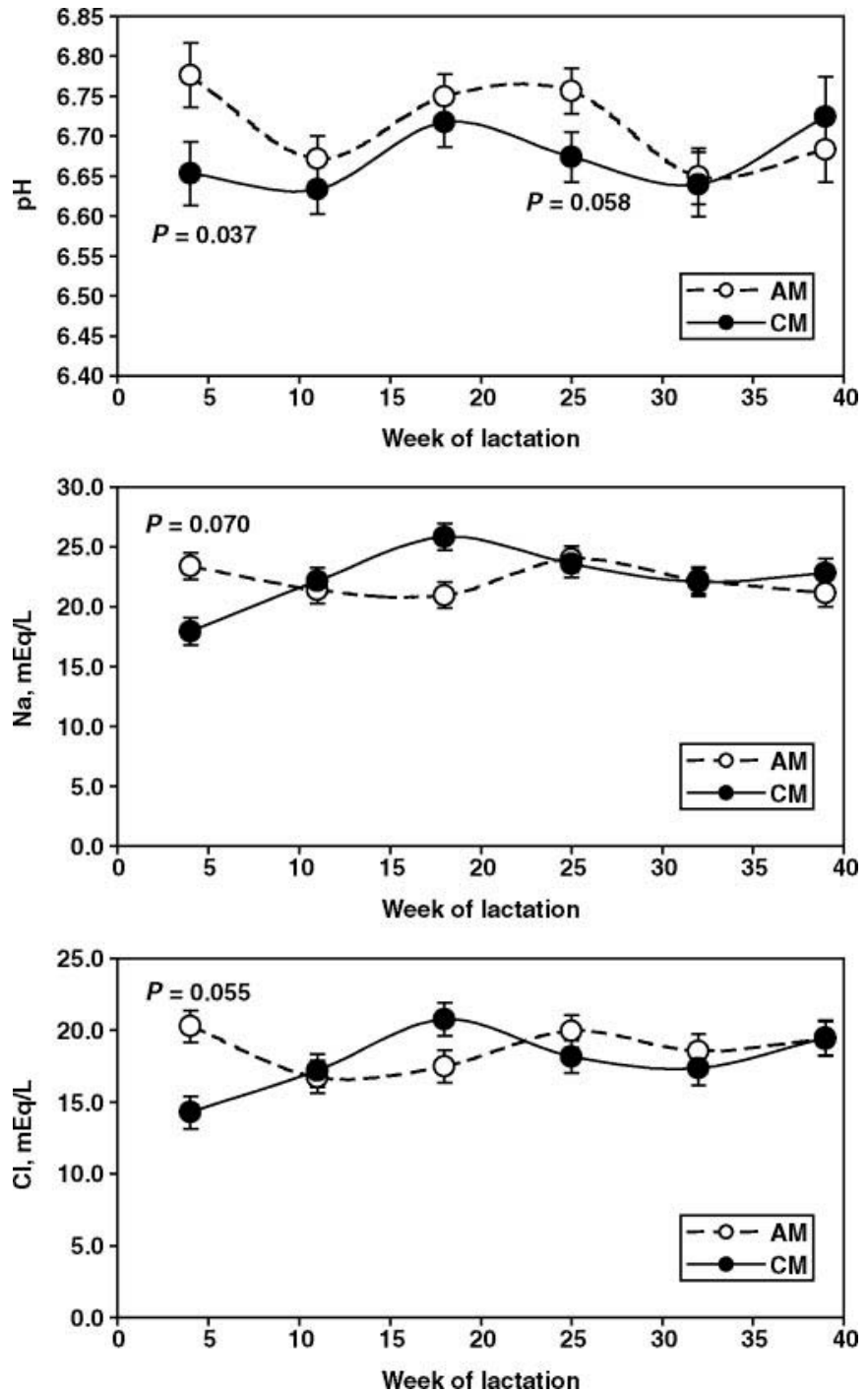

Figure 7. Milk $\mathrm{pH}$, and $\mathrm{Na}$ and $\mathrm{Cl}$ concentrations in milk from cows in the conventional milking system $(\mathrm{CM})$ and in the automatic milking (AM) system throughout the 39 wk of the trial. Data represent least squares means \pm SEM. When means within week of lactation were different, or a trend was evident, the $P$-value was reported above them. were compared. The metabolic profile suggests a slight difficulty on the part of AM primiparous cows in coping with their productive performances in early lactation. Considering the low MF in the first month of lactation, probably linked to low access to the feeding lane in the forced traffic system, some minor metabolic changes in AM, when compared with $\mathrm{CM}$, may be related to reduced daily DMI, rather than its modified daily pattern. Early lactation of AM cows may give rise to a crucial situation because the expected increase in MF can be delayed. Nevertheless, the major milk component and udder health did not differ between MS.
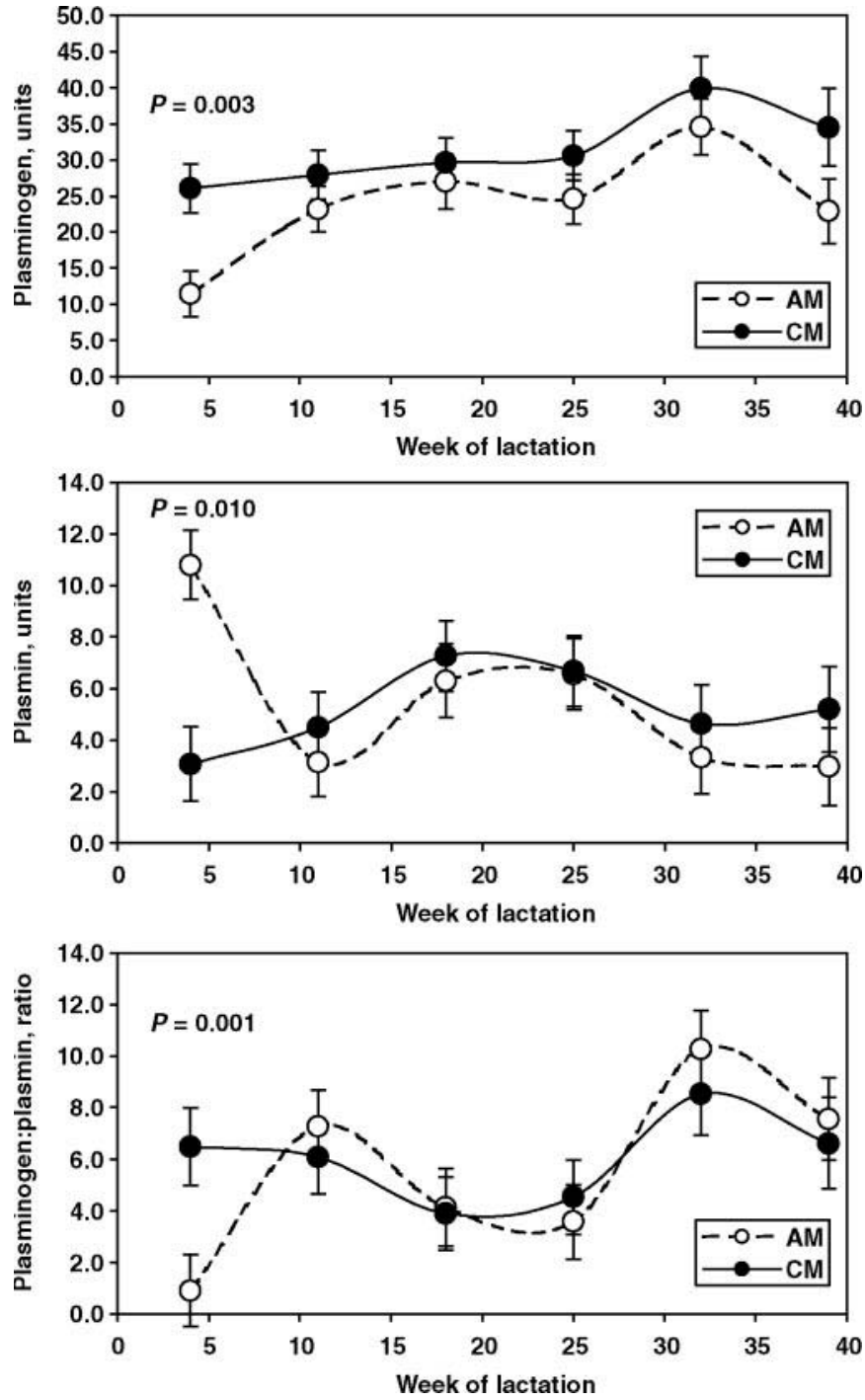

Figure 8. Plasminogen, plasmin, and plasminogen/plasmin ratio in milk from cows in the conventional milking system (CM) and in the automatic milking (AM) system throughout the 39 wk of the trial. Data represent least squares means \pm SEM. When means within week of lactation were different, or a trend was evident, the $P$-value was reported above them. 
The study showed that milk $\mathrm{pH}$ was greater in AM, but the lack of difference in electrolyte concentration suggests that MS did not affect mammary epithelial permeability through 39 WOL. However, the first month of lactation, when the irregular MF may lead to an excessively extended lag between milkings, was a critical point. In that stage, the greater milk $\mathrm{pH}$ in $\mathrm{AM}$ led to increased $\mathrm{Pl}$ activity due to the increased conversion of its precursor pl. Further studies will be necessary to assess how this increased enzymatic activity could affect milk nitrogen fractions and, as a consequence, cheese-making features.

\section{ACKNOWLEDGMENTS}

This study was funded within the Project "Robot di Mungitura (RdM $2^{a}$ fase)," Subproject 2 "Effetto della mungitura robotizzata sulla fisiologia della lattazione" by the Agriculture Department of Regione Lombardia (Programma regionale di ricerca 2001-2003). We also thank Franco Sangiorgi, University of Milan, who coordinated the project.

\section{REFERENCES}

Abeni, F., L. Calamari, F. Calza, M. Speroni, G. Bertoni, and G. Pirlo. 2005a. Welfare assessment based on metabolic and endocrine aspects in primiparous cows milked in a parlor or with an automatic milking system. J. Dairy Sci. 88:3542-3552.

Abeni, F., L. Degano, F. Calza, R. Giangiacomo, and G. Pirlo. 2005b. Milk quality and automatic milking: Fat globule size, natural creaming, and lipolysis. J. Dairy Sci. 88:3519-3529.

Bach, A., and I. Busto. 2005. Effects on milk yield of milking interval regularity and teat cup attachment failures with robotic milking systems. J. Dairy Res. 72:101-106.

Bernabucci, U., B. Ronchi, N. Lacetera, and A. Nardone. 2005. Influence of body condition score on relationships between metabolic status and oxidative stress in periparturient dairy cows. J. Dairy Sci. 88:2017-2026.

Boutinaud, M., C. Rousseau, D. H. Keisler, and H. Jammes. 2003. Growth hormone and milking frequency act differently on goat mammary gland in late lactation. J. Dairy Sci. 86:509-520.

Calza, F., F. Abeni, L. Calamari, and G. Pirlo. 2005. Effects of automatic milking system on some plasma parameters related to oxidative status in primiparous dairy cows. Proceedings of the ASPA 16th Congress. C. Lazzaroni, L. Di Stasio, E. Tartari, G. Masoero, D. Biagini, L. M. Battaglini, D. Bergero, P. P. Mussa, A. Schiavone, and I. Zoccarato, ed. Ital. J. Anim. Sci. 4 (Suppl. 2), 209-211.

Dahl, G. E., R. L. Wallace, R. D. Shanks, and D. Lueking. 2004. Hot Topic: Effects of frequent milking in early lactation on milk yield and udder health. J. Dairy Sci. 87:882-885.

Delamaire, E., and J. Guinard-Flament. 2006a. Increasing milking intervals decreases the mammary blood flow and mammary uptake of nutrients in dairy cows. J. Dairy Sci. 89:3439-3446.

Delamaire, E., and J. Guinard-Flament. 2006b. Longer milking intervals alter mammary epithelial permeability and the udder's ability to extract nutrients. J. Dairy Sci. 89:2007-2016.

Drackley, J. D., H. M. Dann, G. N. Douglas, N. A. J. Guretzky, N. B. Litherland, J. P. Underwood, and J. J. Loor. 2005. Physiological and pathological adaptations in dairy cows that may increase susceptibility to periparturient diseases and disorders. Ital. J. Anim. Sci. 4:323-344.

Edmonson, A. J., I. J. Lean, L. D. Weaver, T. Farver, and G. Webster. 1989. A body condition scoring chart for Holstein dairy cows. J. Dairy Sci. 72:68-78.

Gygax, L., I. Neuffer, C. Kaufmann, R. Hauser, and B. Wechsler. 2007. Comparison of functional aspects in two automatic milking systems and auto-tandem milking parlors. J. Dairy Sci. 90:4265-4274.

Hale, S. A., A. V. Capuco, and R. A. Erdman. 2003. Milk yield and mammary growth effects due to increased milking frequency during early lactation. J. Dairy Sci. 86:2061-2071.

Harms, J., G. Wendl, and H. Schön. 2002. Influence of cow traffic on milking and animal behaviour in a robotic milking system. Pages II-8-II-14 in The First North American Conference on Robotic Milking. Wageningen Pers, Wageningen, the Netherlands.

Ketelaar-de Lauwere, C. C., M. M. W. B. Hendriks, J. H. M. Metz, and W. G. P. Schouten. 1998. Behaviour of dairy cows under free or forced cow traffic in a simulated automatic milking system environment. Appl. Anim. Behav. Sci. 56:13-28.

Knight, C. H., M. Peaker, and C. J. Wilde. 1998. Local control of mammary development and function. Rev. Reprod. 3:104-112.

Lacy-Hulbert, S. J., M. W. Woolford, G. D. Nicholas, C. G. Prosser, and K. Stelwagen. 1999. Effect of milking frequency and pasture intake on milk yield and composition of late lactation cows. J. Dairy Sci. 82:1232-1239.

Le Roux, Y., F. Laurent, and F. Moussaoui. 2003. Polymorphonuclear proteolytic activity and milk composition change. Vet. Res. 34:629-645

Martillotti, F., M. Antongiovanni, L. Rizzi, E. Santi, and G. Bittante. 1987. Metodi di analisi per la valutazione degli alimenti di impiego zootecnico. Quaderno metodologico n. 8, IPRA-CNR, Rome, Italy.

National Research Council. 2001. Nutrient Requirements of Dairy Cattle. 7th rev. ed. National Academy Press, Washington, DC.

Patton, J., D. A. Kenny, J. F. Mee, F. P. O’Mara, D. C. Wathes, M. Cook, and J. J. Murphy. 2006. Effect of milking frequency and diet on milk production, energy balance, and reproduction in dairy cows. J. Dairy Sci. 89:1478-1487.

Pirlo, G., G. Bertoni, and R. Giangiacomo. 2004. Introduction of AMS in Italian dairy herds: Effects on cow performances and milk quality in a herd of the Grana Padano area. Pages 335-340 in Automatic Milking. A Better Understanding. A. Meijering, H. Hogeveen and C. J. A. M. de Koning. Wageningen Academic Publishers, Wageningen, the Netherlands.

Pirlo, P., F. Abeni, M. Cappelletti, L. Migliorati, and M. Speroni. 2005. Automation in dairy cattle milking: Experimental results and consideration. Ital. J. Anim. Sci. 4 (Suppl. 3):17-25.

Politis, I., K. F. Ng Kwai Hang, and R. N. Giroux. 1989. Environmental factors affecting plasmin activity in milk. J. Dairy Sci. 72:17131718.

Schaar, J. 1985. Plasmin activity and proteose-peptone content of individual milks. J. Dairy Res. 52:369-378.

Shamay, A., F. Shapiro, G. Leitner, and N. Silanikove. 2003. Infusions of casein hydrolyzates into the mammary gland disrupt tight junction integrity and induce involution in cows. J. Dairy Sci. $86: 1250-1258$.

Shennan, D. B., and M. Peaker. 2000. Transport of milk constituents by the mammary gland. Physiol. Rev. 80:925-951.

Sorensen, A., D. D. Muir, and C. H. Knight. 2001. Thrice-daily milking throughout lactation maintains epithelial integrity and thereby improves milk protein quality. J. Dairy Res. 68:15-25.

Speroni, M., G. Pirlo, and S. Lolli. 2006. Effect of automatic milking systems on milk yield in a hot environment. J. Dairy Sci. 89:4687-4693.

Spolders, M., U. Meyer, G. Flachowsky, and M. Coenen. 2004. Differences between primiparous and multiparous cows in voluntary milking frequency in an automatic milking system. Ital. J. Anim. Sci. 3:167-175. 
Stelwagen, K., V. C. Farr, and H. A. McFadden. 1999. Alteration of the sodium to potassium ratio in milk and the effect on milk secretion in goats. J. Dairy Sci. 82:52-59.

Stelwagen, K., I. Politis, J. H. White, B. Zavizion, C. G. Prosser, S. R. Davis, and V. C. Farr. 1994. Effect of milking frequency and somatotropin on the activity of plasminogen activator, plasminogen, and plasmin in bovine milk. J. Dairy Sci. 77:35773583.

Svennersten-Sjaunja, K. M., and G. Pettersson. 2008. Pros and cons of automatic milking in Europe. J. Anim. Sci. 86(Suppl. 1):3746.

Wenzel, C., and A. Nitzschke. 2004. Study on the incidence of ketosis in dairy cows in an automatic milking system versus a conventional milking system. Pages 184-185 in Automatic Milking. A Better Understanding. A. Meijering, H. Hogeveen and C. J. A. M. de Koning, Wageningen Academic Publishers, Wageningen, the Netherlands.

Wiktorsson, H., G. Pettersson, J. Olofsson, K. Svennersten-Sjaunja, and M. Melin. 2003. Welfare status of dairy cows in barns with automatic milking. Relations between the environment and cow behaviour, physiologic, metabolic and performance parameters. Report of the EU project "Implication of the introduction of automatic milking on dairy farms" (QLK5-2000-31006) as part of the EU-program "Quality of Life and Management of Living Resources". Deliverable D24, March 2003, 40 pp. http://www. automaticmilking.nl Accessed Aug. 8, 2003. 